\title{
Examining the Validity of Wagner's Law in the OECD Economies
}

\author{
Metin Bayrak $^{1} \&$ Ömer Esen ${ }^{2, *}$ \\ ${ }^{1}$ Department of Economics, Ataturk University, Erzurum, Turkey \\ ${ }^{2}$ Department of Economics, Mus Alparslan University, Mus, Turkey \\ *Corresponding author: Department of Economics, Faculty of Economics and Administrative \\ Sciences, Mus Alparslan University, 49250, Mus, Turkey. E-mail: o.esen@alparslan.edu.tr
}

Received: March 24, 2014 Accepted: July 9, 2014 Published: August 26, 2014

doi:10.5296/rae.v6i3.5354 URL: http://dx.doi.org/10.5296/rae.v6i3.5354

\begin{abstract}
In this study, the validity of Wagner's Law, which explains the relationship between public expenditures and economic growth, has been analyzed over its alternative models by using the data from 27 OECD economies between the years 1995- 2012. It has been carried out by utilizing unit root, co-integration and error correction tests panel data analyses, the long term co-efficiencies between public expenditures and economic growth. In order to test the relationship of co-integration, the Pedroni, Johansen-Fisher and Westerlund co-integration tests were utilized, whereas for the predictions of the long term co-efficiencies, the DOLS predictor was utilized. In addition, the PMGE and MGE error correction models were benefited from for predicting the short term parameters between the variables.
\end{abstract}

Keywords: Public expenditures; Economic growth; Wagner's law; Panel data analysis

JEL Classification: O40, H50, C23 


\section{Introduction}

Government expenditures came into prominence with the formation of the phenomenon known as the state, which is the most modern organizational method to meet social needs. Then, along with the changes on the mission and functions of the state from era to era, they began to specify a new meaning with each new era. From the past to the present, due to many socio-economic reasons, such as overcoming the negative effects of wars in developed or developing countries, performing social security services, making infrastructural investments anticipated by industrialization, broadly accepting the opinion that the fight against unemployment and other economic instabilities fall under the main functions of the state, government expenditures have increased rapidly. Also, the fact that the state has become one of the most prominent actors in economic life today and resorts to expenditures constantly, with or without intention, has a share in this increase. The never slowing down and unstoppable increase of government expenditures throughout history have attracted the attention of many scientists, especially Adolph Wagner and the effects of government expenditures on economies have been a much debated issue.

There are two major opinions available in the literature of economy; asserting that there is a positive causality relationship between government expenditures and economic growth. Within this context, the relationship between government expenditures and economic growth was first examined by German economist Wagner (1883). As the result of his studies conducted on the course of government expenditures, Wagner revealed that the speed of increase in government expenditures was higher than the speed of increase in national income. (Kumar et al., 2012: 607) In other words, he indicated that the income elasticity of the demand for governmental expenditures was higher than 1 and governmental expenditures would increase annually more than the increase rate of the national income (Koop and Poirier, 1995: 123). Therefore, the opinion Wagner adopted is characterized as the "Law of Governmental Expenditure Increase" in the literature of economy. Governmental expenditures are regarded as an internal variable and it is indicated that the direction of causality takes a course from economic growth to governmental expenditures (Bird, 1971: 2). This opinion, asserted as a hypothesis by Wagner, which was then named as "Wagner's Law", constituted a basis for many theoretical and empiric studies.

Another opinion that bears significance regarding the relationship between government expenditures and economic growth is the Keynesian approach. Within the scope of this approach, it is accepted that, government expenditures are external factors that can be utilized as policy tools designed to influence government expenditures as well as economic growth and to influence the short term fluctuations. It is also acknowledged that, like in Wagner's approach, there is a positive causality relation between government expenditures and economic growth. However, unlike in Wagner's law, the causality relation here is reflected towards the point that the increase in governmental expenditures, which are considered as an external variable here, shall cause an increase in the national income, thus the causality shall occur towards the course from governmental expenditures to economic growth.

Knowing the direction of the causality between governmental expenditures and economic 
growth is of great importance in terms of economic policy making. In this context, if the causality proposed by the aforementioned Keynesian Approach is the case between governmental expenditures and economic growth, governmental expenditures become a significant political tool. Conversely, if the causality is considered towards the direction stipulated by Wagner's Law, then the influence of governmental expenditures to be an effective policy tool for economic growth declines (Singh and Sahni, 1984: 630). At this point, discussing Wagner's Law, which suggests that the increase in governmental expenditures emerges as a result of progress and development; and the Keynesian Approach, which connects economic growth to the increase in governmental expenditures, bears vital importance.

There have been many studies conducted to examine the validity of Wagner's Law hence there is a good deal of literature available regarding the subject. The validity of Wagner's Law has been assessed and evaluated by using various econometric methods for different countries in an empiric way. Some of the results extracted from such studies offer supportive evidence (Oxley 1994; Ahsan et al. 1996; Kolluri et al. 2000; Sideris 2007; Kumar et al. 2012), while some present contrary evidence (Courakis et al. 1993; Koop and Poirier 1995; Afxentiou and Serletis 1996; Ansari et al. 1997; Chow et al. 2002; Burney 2002).

Although a large number of significant studies regarding Wagner's Law, which have reached various and different conclusions in relation to one another, do exist in the literature, some are multinational in nature and some single national. Within this context, as an example of the multinational works, Koop and Poirier (1995) examined the validity of Wagner's hypothesis based on the data obtained from 86 countries by the error correction method with two variables, which corresponds to the co-integration method. The findings suggest that, verifying the validity of Wagner's hypothesis in just three of the examined countries does not necessarily mean that the hypothesis is valid in general.

Ansari et al. (1997) analysed the validity of Wagner's Law with Granger and Holmes Hutton tests for three African countries, namely Ghana (1963 - 1988), Kenya (1964-1989) and South Africa (1957-1990) by utilising the data regarding public expenditure per capita and GNP. According to the results of the analysis; out of the countries studied, only Ghana produces findings that support the Wagner Hypothesis, while no supportive findings for the other two countries have ever been found.

Kolluri et al (2000), in their works, examined the relationship between public expenditures and national income by utilising the time series data of the industrialised G7 countries, comprised of Canada, France, Italy, Japan, England, the USA and Germany within the period of 1960-1993. The results of the studies, in a way, support Wagner's Law, indicate the presence of a long term equilibrium relationship between governmental expenditures and national income. Chang, (2002) by using the annual time series of six countries namely South Korea, Taiwan, Thailand, Japan, the USA and Great Britain, analysed Wagner's Law in the scope of 5 different relevant models in the literature. The results of the analysis suggest that, there is a long term relationship between the income and public expenditures for all of the examined countries, with the exception of Thailand; and in addition to that, the results 
also asserted evidence regarding the validity of Wagner's Law. Lamartina and Zaghini (2011) in their study covering the period of 1970-2006, examined the validity of Wagner's Law for 23 OECD countries by utilising the data regarding public expenditures and GDP per capita. The results of the analysis; being coherent with Wagner's Law, unveiled the presence of a structurally positive relationship between public expenditures and GDP per capita. Within this context, the results also indicated that, the rate of increase in public expenditures is higher than the rate of increase experienced in the revenue. In addition to this, the study also underlined that the aforementioned relation is higher in the countries with lower GDP per capita.

In the relevant literature, the examples of the single nation based studies that analyse the validity of Wagner's Law are as follows;

Oxley (1994) studied the validity of Wagner's Law for the British economy covering the period of 1870-1913 by means of co-integration and causality analyses. The results obtained from the study presented evidence that was consistent with Wagner's Hypothesis. Selen and Eryiğit (2009), by using the time series comprised of the sum of public expenditures regarding the period of 1923-2006, GDP and census data, dissected the validity of Wagner's Law from the standpoint of Turkey. The results of their analyses determined the presence of a positive directional interaction that proceeds from GDP towards public expenditure, in a way that supports Wagner's Law.

Burney, (2002) analysed the validity of Wagner's Law for Kuwait based on the time series data, generated for the period of 1969-1995 with co-integration and error correction models. According to the results, no findings supporting the validity of Wagner's Law have been discovered. Basar et al. (2009), in their studies, tested the relationship between public expenditures and economic growth in Turkey, within the scope of Wagner's approach with the limit test method by using the data from the period of 1975-2005. The results of their analyses indicate that, there is no long term relationship present between investments, transfer expenditures and GDP. Within this context, as per the relevant sub items for the indicated period, it is pointed out that, the hypotheses of Wagner regarding public expenditures are not valid for Turkey.

Chow et al. (2002) examined the relationship between public expenditures and economic growth in a two variable system by using the data of Great Britain for the period of 1948-1997 in order to test the validity of Wagner's law in the long term. The outcome of the analysis did not indicate a long term co-integrated relationship in the two variable models belonging to public expenditures and economic growth. However, when a third variable was included in the model (money supply), it was observed that, the relationship between public expenditures and economic growth was re-established. In addition, the results of the Granger causality test provided strong support for Wagner's Hypothesis, therefore indicating a unidirectional causality relationship in the long term, from income and money supply towards public expenditures.

The purpose of this study is to analyse the validity of Wagner's Law, which explains the relationship between public expenditures and economic growth in an empiric way by utilizing 
the data of 27 OECD economies regarding the term 1995-2012. In line with this purpose, the general information related to the subject is principally provided hereby in this study, and other works that analyse the relationship between public expenditure and economic growth are further reviewed. Afterwards, by providing information on the data set and the econometric method to be utilized, the empiric implementation is exercised. In the last phase of the study, the findings, which were obtained as the result of the implementation, are presented, and a general assessment has been made in comparison with the current literature.

\section{Model, Data and the Implemented Econometric Methodology}

In this study, Wagner's Law, which is also known as the law of increasing state spending, shall be dissected in a manner specific to 27 OECD countries (Austria, Belgium, Canada, Czech Republic, Denmark, Estonia, Finland, France, Germany, Greece, Hungary, Ireland, Israel, Italy, South Korea, Luxembourg, Netherlands, Norway, Portugal, Slovak Republic, Slovenia, Spain, Sweden, Switzerland, United Kingdom, USA and Turkey) by utilising panel unit root and panel co-integration analyses. Within this scope, the data of the said countries that belong to the period of 1995-2012 were extracted by compiling the databases of OECD's Factbook 2011-2012 Economic, Environmental and Social Statistics and World Bank's World Development Indicators (WDI) and Global Development Finance (GDF). The accessibility was the primal determinative for selecting the economies and the period that were discussed within the scope of the analysis.

Regarding Wagner's Law, which essentially presents the relationship between public expenditures and economic growth, many different model versions appear in the relevant literature. It is also very likely to come across studies in the literature that include one or more of the indicated models. In this sense, the most widely used models in the studies, which attempt to explain the validity of Wagner's Law or analyse it, are indicated in Table 1.

Table 1. Alternative models for Wagner's Law

\begin{tabular}{lllll}
\hline Model 1 & $\mathrm{LnG}_{\mathrm{it}}=\beta_{0}+\beta_{1} \mathrm{LnGDP}_{\mathrm{it}}+\varepsilon_{\mathrm{it}}$ & Peacock-Wiseman (1961) & $\beta_{1}>1$ & $(1)$ \\
\hline Model 2 & $\mathrm{LnperG}_{\mathrm{it}}=\beta_{0}+\beta_{1}$ LnperGDP $_{\mathrm{it}}+\varepsilon_{\mathrm{it}}$ & Gupta (1967) & $\beta_{1}>1$ & $(2)$ \\
\hline Model 3 & $\mathrm{LnG}_{\mathrm{it}}=\beta_{0}+\beta_{1}$ LnperGDP $_{\mathrm{it}}+\varepsilon_{\mathrm{it}}$ & Goffman (1968) & $\beta_{1}>1$ & $(3)$ \\
\hline Model 4 & $\mathrm{LnG} / \mathrm{GDP}_{\mathrm{it}}=\beta_{0}+\beta_{1} \mathrm{LnGDP}_{\mathrm{it}}+\varepsilon_{\mathrm{it}}$ & Mann (1980) & $\beta_{1}>0$ & $(4)$ \\
\hline Model 5 & $\mathrm{LnG} / \mathrm{GDP}_{\mathrm{it}}=\beta_{0}+\beta_{1}$ LnperGDP $_{\mathrm{it}}+\varepsilon_{\mathrm{it}}$ & Payne-Ewing (1996) & $\beta_{1}>0$ & $(5)$ \\
\hline
\end{tabular}

According to the model tested by Peacock-Wiseman (1961) (Model 1), public expenditures are a function of national income, so when national income increases, public expenditures would also increase. According to this model; $\operatorname{Ln} G_{i}$, indicates the logarithmic value of public expenditure series and $L n G D P_{i t}$ indicates the logarithmic value of the series belonging to the 
variable of real GDP. In this model, the income elasticity of the public expenditures $\left(\beta_{1}\right)$ should be greater than one, in order to render Wagner's Law valid and applicable.

In Gupta's model (1967), however, (Model 2) public expenditures were considered as the function of real GDP per capita. According to this model; $L n p e r G_{i t}$ corresponds to the logarithmic value of the series, belonging to public expenditures per capita and LnperGDP $P_{i t}$ represents the logarithmic value of the series, belonging to the variable of GDP. In this model, in order for Wagner's Law to prove valid, the income elasticity of real public expenditures $\left(\beta_{1}\right)$ should be greater than one.

In Goffman's version (1968), which is discussed as the third model, (Model 3) public expenditures are a function of reel GDP per capita and as long as GDP per capita rises, so shall public expenditures. According to this model, the validity of Wagner's Law depends on the income elasticity of real public expenditures $\left(\beta_{1}\right)$ being greater than one. This elasticity, being less than one indicates the invalidity of Wagner's Law. In the model, as opposed to the Peacock-Wiseman (1961) model, instead of the logarithmic value of real GDP, the logarithmic value of the GDP per capita was taken into account.

Yet in another model, Mann (1980) (Model 4), apart from others, the dependent variable, which is $L n G / G D P_{i t}$ was stated as the logarithmic value of the share of real public expenditures within real GDP. Also, according to this model, Wagner's Law gains validity in the case where income elasticity of public expenditures $\left(\beta_{l}\right)$ is greater than zero.

In the Payne-Ewing (1996) model, (Model 5) the ratio of real public expenditures within real GDP is stated as a function of real GDP per capita. In this model, different from the Mann (1980) model, instead of the logarithmic value of real GDP, the logarithmic value of real GDP per capita was taken into account. In addition to that, for Wagner's Law to be valid, the $\beta_{1}$ co-efficient should be greater than zero.

Also, $\varepsilon_{t}$ which takes part in the models is the error term. The $\mathrm{i}$, given here, indicates the units within the horizontal cross section $(i=1, \ldots, n)$, and $t$, given above, indicates the size of the time series of each of the units.

In order to refer to a relationship of co-integration between the variables of a data set, series with panel characteristics belonging to the used variables, possessing stable properties is important. In this sense, before performing the panel analysis, it should be decided whether the series belonging to the models are constant or not, and in the case that they are constant, unit root tests should be performed in order to determine at what level they are constant. Therefore, in this study, the variables to be analysed are tested for panel data with unit root tests, developed by Levin, Lin and Chu (2002), Im, Pesaran and Shin (2003), Maddala and $\mathrm{Wu}(1999)$ and Choi (2001).

In the study, the presence of a long term relationship between the variables is tested by co-integration analyses. In this context, the long term relationship between the variables are examined by some of the most commonly used panel co-integration analyses in the literature; the Pedroni, Johansen Fisher and Westerlund tests. 
After determining that all the variables are constant by the very same degree, as indicated by the results of the unit root tests, the co-integration analysis was conducted; and therefore, the presence of a long term relationship between the variables was examined. The fact that whether there is a co-integration between the panel data variables or not was initially studied by the Pedroni (1999-2004) panel co-integration test. In the Pedroni co-integration analysis, whether the panel data is co-integrated or not is examined by seven co-integration tests, comprised of four within-dimension tests (panel v, panel rho, panel PP and panel ADF), and three between-dimension tests (group rho, group PP and group ADF). Another co-integration analysis, conducted towards the variables, is the Johansen-Fisher type panel co-integration test, recommended by Maddala and $\mathrm{Wu}$ (1999). The Johansen-Fisher type panel co-integration test is the panel version of the individual Johansen co-integration test. In this study, the final test that was utilized in order to test the co-integration relationship between the variables is the error correction model based panel co-integration test that was developed by Westerlund $(2006,2007)$. In order to test the presence of co-integration, Westerlund suggests four panel co-integration statistics. Two of those statistics are based on the assumption that the auto-regressive parameter is constant for all units and are considered as panel co-integration statistics (Panel Statistics: $\mathrm{Pa}, \mathrm{Pt}$ ). The other two statistics, on the other hand, are based on the assumption that the auto-regressive parameters vary from unit to unit, therefore they are known as group mean co-integration statistics (Group Mean Tests: Ga, Gt).

According to the results from the panel co-integration tests conducted within the scope of this study; by determining the presence of a long term relationship between the variables, a need for estimation for the common long term coefficients arises. Within this context, after the presence of the long term relationship is revealed by the co-integration test, the coefficients of the co-integration vectors are analyzed by the DOLS (Dynamic Ordinary Least Square) prediction method, suggested by Stock and Watson (1993) and Kao and Chiang (2001).

The Panel Dynamic OLS method is utilized only to predict the long term parameters. And, in reality, apart from the long term parameters, the short term parameters also provide essential information. In this regard, both the long and short term parameters between the aforementioned variables are analyzed by the Pooled Mean Group Estimation (PMGE) and Mean Group Estimation (MGE) error correction methods, suggested by Pesaran and Smith (1995) and Pesaran et al. (1999).

\section{Results and Discussions}

\subsection{Panel Unit Root Test Results}

In order to obtain econometrically significant relations between the variables, the series to be analysed should be constant. For this reason, first of all, the series to be used in the model should also be tested in order to determine whether or not they are constant. In this sense, the stability of the variables was examined first. For testing the series to be used whether they are constant or not, the panel unit root tests, which are also termed as first generation panel root tests, developed by Levin, Lin and Chu (2002), Im, Pesaran and Shin (2003), Maddala and 
$\mathrm{Wu}$ (1999) with Choi (2001), were utilised. The results of the unit root tests, applied to the variables, which are present in all of the models that present the different versions of Wagner's Law, can be seen in Table 2.

Table 2. Panel unit root test results

\begin{tabular}{|c|c|c|c|c|}
\hline Variables & $\begin{array}{c}\text { Levin, Lin \& Chu } \\
\text { (LLC) } \\
\text { t-stat }\end{array}$ & $\begin{array}{c}\text { Im, Pesaran \& Shin } \\
\text { (IPS) } \\
\text { w-stat } \\
\end{array}$ & $\begin{array}{c}\text { ADF-Fisher } \\
\text { (Maddala and } \mathrm{Wu}) \\
\mathrm{x}^{2} \text {-stat }\end{array}$ & $\begin{array}{c}\text { PP-Fisher } \\
\text { (Choi) } \\
x^{2} \text {-stat }\end{array}$ \\
\hline $\ln G_{i t}$ & 2.66809 & 8.34347 & 15.7656 & 21.9646 \\
\hline$D \ln G_{i t}$ & $-1.72016^{* *}$ & $-4.90142 *$ & $113.114^{*}$ & $246.130^{*}$ \\
\hline lnperG $\mathrm{it}_{\mathrm{it}}$ & 2.21854 & 8.04285 & 16.0725 & 22.7184 \\
\hline DlnperG $_{i t}$ & $-1.48503 * * *$ & $-4.94225 *$ & $114.301 *$ & $246.511 *$ \\
\hline $\operatorname{lnGDP}_{\text {it }}$ & 5.52575 & 1.97337 & 27.9679 & 34.3197 \\
\hline $\mathrm{D}_{\ln G D P_{i t}}$ & $-1.48671 * *$ & $-3.39123 *$ & $90.0209^{*}$ & $154.103^{*}$ \\
\hline $\operatorname{lnperGDP}_{\text {it }}$ & 5.64586 & 1.60251 & 30.7216 & 37.8256 \\
\hline DlnperGDP $_{\text {it }}$ & $-1.39331 * * *$ & $-3.23592 *$ & $88.0025^{*}$ & $152.951 *$ \\
\hline $\operatorname{lnG} / \mathrm{GDP}_{\mathrm{it}}$ & -0.54809 & 1.39133 & 45.1954 & $74.7590 * *$ \\
\hline $\mathrm{D} \operatorname{lnG} / \mathrm{GDP}_{\mathrm{it}}$ & $-6.08382 *$ & $-4.06964 *$ & $104.675^{*}$ & $218.402 *$ \\
\hline
\end{tabular}

Notes: Probabilities for Fisher-type tests are computed using an asymptotic $\chi 2$ distribution. Levin, Lin \& Chu and $\mathrm{lm}$, Pesaran \& Shin tests assume asymptotic normality. Also *1\%,**5\% and ***10\% significant at the test values.

As shown in Table 2, when the test results for the indicated variables for the LLC, IPS, ADF and PP panel unit root analysis are examined, it is seen that, the series are not constant at the significance level of 5\%, meaning that they contain a unit root. Therefore, the difference from the first degree of each of the series was taken. In this way, it is observed that the variables become constant. According to these results, it is safe to say that, the variables are integrated in the same level and it is possible to analyse a relationship in the long term, which can be possible by the co-integration tests.

\subsection{The Results of the Panel Data Cointegration Analysis}

In this study, the presence of a long term relationship between the variables, in terms of different models that explain the relationship between public expenditures and economic growth, was tested by means of co-integration analyses. In this regard, the long term relationship between the variables was studied by utilising the Pedroni, Johansen Fisher and Westerlund Tests, which are amongst the most widely used panel co-integration tests.

At first, the co-integration relation between the indicated variables was determined by the Pedroni Panel Test, and the results for the 27 OECD countries studied are presented in Table 3. 
Table 3. Pedroni panel cointegration test results

\begin{tabular}{cccccccc}
\hline \multirow{2}{*}{ Models } & $\begin{array}{c}\text { Panel } \\
\mathrm{v}\end{array}$ & $\begin{array}{c}\text { Panel } \\
\text { rho }\end{array}$ & $\begin{array}{c}\text { Panel } \\
\text { PP }\end{array}$ & $\begin{array}{c}\text { Panel } \\
\text { ADF }\end{array}$ & $\begin{array}{c}\text { Group } \\
\text { rho }\end{array}$ & $\begin{array}{c}\text { Group } \\
\text { PP }\end{array}$ & $\begin{array}{c}\text { Group } \\
\text { ADF }\end{array}$ \\
\hline Model 1 & $4.6375^{*}$ & $-1.2947^{* * *}$ & $-1.3633^{* * *}$ & $-2.0178^{* *}$ & 0.9432 & $-1.5980^{* *}$ & $-2.9320^{*}$ \\
Model 2 & $4.2205^{*}$ & -1.2153 & -1.2731 & $-1.9755^{* *}$ & 0.9467 & $-1.5198^{* *}$ & $-2.8611^{*}$ \\
Model 3 & $4.1983^{*}$ & -0.6470 & -0.5729 & $-1.9238^{* *}$ & 1.3101 & -1.0336 & $-3.1287^{*}$ \\
Model 4 & $4.2444^{*}$ & -1.1853 & -1.2042 & $-1.8920^{* *}$ & 0.9750 & $-1.4561 * *$ & $-2.7632^{*}$ \\
Model 5 & $4.6422^{*}$ & $-1.2838^{* * *}$ & $-1.3543^{* * *}$ & $-1.9919^{* *}$ & 0.9771 & $-1.5560^{* *}$ & $-2.9369^{*}$ \\
\hline
\end{tabular}

$* 1 \%, * * 5 \%$ and $* * * 10 \%$ significant at the test values.

As it is seen in Table 3, the panel test co-integration results developed by Pedroni (1999 and 2004) indicate that, the zero hypothesis, formulated as "no co-integration relation exist" is rejected for a fixed model at a significance level of $10 \%$ in a statistically significant manner in all the models, with the exception of Model 3. In this context, the results of the analysis within the scope of the different models that present the relationship between the public expenditure and economic growth point out the presence of a statistically significant and long term relationship between the two variables.

Finally, within the scope of the models that present the relationship between public expenditures and economic growth, the long term relationship between the variables was analysed by means of Johansen Fisher co-integration analysis. The results of the analysis are presented in Table 4.

Table 4. Johansen Fisher panel cointegration test results

\begin{tabular}{cccccc}
\hline \multirow{2}{*}{ Models } & No. of CE(s) & $\begin{array}{c}\text { Fisher } \lambda_{\text {trace }} \\
\text { Statistic }\end{array}$ & Prob.* & $\begin{array}{c}\text { Fisher } \lambda_{\max } \\
\text { Statistic }\end{array}$ & Prob.* \\
\hline \multirow{2}{*}{ Model 1 } & $\mathrm{H}_{0}: \alpha_{\mathrm{it}}=0, \mathrm{H}_{1}: \alpha_{\mathrm{it}} \geq 1$ & 112.5 & 0.0000 & 114.3 & 0.0000 \\
& $\mathrm{H}_{0}: \alpha_{\mathrm{it}} \leq 1, \mathrm{H}_{1}: \alpha_{\mathrm{it}} \geq 2$ & 49.97 & 0.6306 & 49.97 & 0.6306 \\
\hline \multirow{2}{*}{ Model 2 } & $\mathrm{H}_{0}: \alpha_{\mathrm{it}}=0, \mathrm{H}_{1}: \alpha_{\mathrm{it}} \geq 1$ & 112.1 & 0.0000 & 112.8 & 0.0000 \\
& $\mathrm{H}_{0}: \alpha_{\mathrm{it}} \leq 1, \mathrm{H}_{1}: \alpha_{\mathrm{it}} \geq 2$ & 53.18 & 0.5061 & 53.18 & 0.5061 \\
\hline \multirow{2}{*}{ Model 3 } & $\mathrm{H}_{0}: \alpha_{\mathrm{it}}=0, \mathrm{H}_{1}: \alpha_{\mathrm{it}} \geq 1$ & 119.2 & 0.0000 & 119.4 & 0.0000 \\
& $\mathrm{H}_{0}: \alpha_{\mathrm{it}} \leq 1, \mathrm{H}_{1}: \alpha_{\mathrm{it}} \geq 2$ & 55.94 & 0.4018 & 55.94 & 0.4018 \\
\hline \multirow{2}{*}{ Model 4 } & $\mathrm{H}_{0}: \alpha_{\mathrm{it}}=0, \mathrm{H}_{1}: \alpha_{\mathrm{it}} \geq 1$ & 110.0 & 0.0000 & 110.6 & 0.0000 \\
& $\mathrm{H}_{0}: \alpha_{\mathrm{it}} \leq 1, \mathrm{H}_{1}: \alpha_{\mathrm{it}} \geq 2$ & 52.81 & 0.5203 & 52.81 & 0.5203 \\
\hline \multirow{2}{*}{ Model 5 } & $\mathrm{H}_{0}: \alpha_{\mathrm{it}}=0, \mathrm{H}_{1}: \alpha_{\mathrm{it}} \geq 1$ & 114.4 & 0.0000 & 116.3 & 0.0000 \\
& $\mathrm{H}_{0}: \alpha_{\mathrm{it}} \leq 1, \mathrm{H}_{1}: \alpha_{\mathrm{it}} \geq 2$ & 50.03 & 0.6281 & 50.03 & 0.6281 \\
\hline
\end{tabular}

* Probabilities are computed using an asymptotic $\chi 2$ distribution

Within the light of the data presented in Table 4, in all of the models, it is seen that, the zero hypothesis is rejected in a statistically significant level, for both the maximum latent value and the trace statistics in relation to the probability values. Therefore, the hypothesis, which asserts that there is a co-integrated vector between the series for 27 OECD economics, was accepted. 
Finally, the results regarding the panel co-integration tests, in which Westerlund suggested error correction based statistics in order to test the co-integration relationship, are given in Table 5.

Table 5. Westerlund ECM panel cointegration tests

\begin{tabular}{lcccc}
\hline Models & $\boldsymbol{G}$ & $\boldsymbol{G a}$ & $\boldsymbol{P t}$ & $\boldsymbol{P a}$ \\
\hline \multirow{3}{*}{ Model 1 } & -10.607 & -5.260 & -12.630 & -26.366 \\
& $(0.000)$ & $(0.969)$ & $(0.000)$ & $(0.000)$ \\
& {$[-51.512]$} & {$[1.861]$} & {$[-4.904]$} & {$[-24.925]$} \\
\hline \multirow{3}{*}{ Model 2 } & -22.092 & -5.030 & -8.139 & -8.962 \\
& $(0.000)$ & $(0.981)$ & $(0.319)$ & $(0.000)$ \\
& {$[-118.642]$} & {$[2.082]$} & {$[-0.471]$} & {$[-5.216]$} \\
Model 3 & -16.933 & -5.628 & -11.208 & -22.111 \\
& $(0.000)$ & $(0.934)$ & $(0.000)$ & $(0.000)$ \\
& {$[-88.489]$} & {$[1.508]$} & {$[-3.501]$} & {$[-20.107]$} \\
Model 4 & -25.830 & -1.496 & -13.287 & -4.191 \\
& $(0.000)$ & $(1.000)$ & $(0.000)$ & $(0.574)$ \\
& {$[-140.489]$} & {$[5.470]$} & {$[-5.553]$} & {$[0.186]$} \\
Model 5 & -21.077 & -1.294 & -8.700 & -3.709 \\
& $(0.000)$ & $(1.000)$ & $(0.153)$ & $(0.768)$ \\
& {$[-112.706]$} & {$[5.664]$} & {$[-1.025]$} & {$[0.732]$} \\
\hline
\end{tabular}

Note: The numbers in the () show the p-value and in the [] show the $\mathrm{z}$-value

Based on the Westerlund panel co-integration results, the null hypothesis, asserting that "there is no co-integration" is rejected in all the models but Model 5. According to this model, it is seen that, there is a co-integration relationship in the panel data set in a statistically significant level. Therefore, according to the results of all the co-integration analyses presented in scope of different models and explaining the relationship between the public expenditures and economic growth, it is safe to say that, a change occurring in the public expenditures in the long run may affect the economic growth.

In conjunction with determining the presence of a long term relationship between the variables, a prediction of the common long term coefficients for all the countries should be made. In this regard, the coefficients of the co-integration vector are analyzed by the Dynamic OLS prediction method. The results of the DOLS predictions which were conducted based on that are provided in Table 6 . 
Table 6. DOLS panel data co-integration estimation results

\begin{tabular}{|c|c|c|c|}
\hline & Models & $\beta_{1}$ & Wald $\chi^{2}$ \\
\hline Model 1 & $\operatorname{LnG}_{i t}-\operatorname{LnGDP}_{\text {it }}$ & $\begin{array}{c}0.9990327^{*} \\
(21.44) \\
{[0.0466063]}\end{array}$ & $459.48 *$ \\
\hline Model 2 & LnperG $_{i t} \quad-$ LnperGDP $_{i t}$ & $\begin{array}{c}1.264381 * \\
(21.06) \\
{[0.0600482]}\end{array}$ & $443.36^{*}$ \\
\hline Model 3 & $\mathrm{LnG}_{\mathrm{it}}-\quad \mathrm{LnperGDP}_{\mathrm{it}}$ & $\begin{array}{c}0.9187468 * \\
(16.71) \\
{[0.0549925]}\end{array}$ & $279.12 *$ \\
\hline Model 4 & $\mathrm{LnG} / \mathrm{GDP}_{\mathrm{it}}-\mathrm{LnGDP}_{\mathrm{it}}$ & $\begin{array}{c}0.2762531 * \\
(2.62) \\
{[0.1052483]}\end{array}$ & $6.89^{*}$ \\
\hline Model 5 & $\begin{array}{l}\mathrm{LnG} \mathrm{GDP}_{\mathrm{it}}- \\
\text { LnperGDP }_{\mathrm{it}}\end{array}$ & $\begin{array}{c}0.262334 * \\
(4.37) \\
{[0.0599987]}\end{array}$ & $19.12^{*}$ \\
\hline
\end{tabular}

* Indicates test statistical significance at the $1 \%$ level. The values in the () are the t-stat. The numbers in the [] show the Std. Err.

In Table 6, the prediction of a long term relationship between the public expenditures and economic growth can be seen. According to the results presented in the table, the T statistic of the long term common coefficient for all the dealt models is significant, and thus, the model is also significant, based on the Wald statistics. According to the results- extracted from the Panel DOLS predictions- conducted within the scope of Model I, which presents the validity of Wagner's Law; the elasticity ratio of the real public expenditures to real GDP in the long run happens to be at the level of 1.00 , which is close to the prior expectations. $\left(\beta_{1}>1\right)$ Therefore, this model supports Wagner's Law, and an increase of 1\% on the real GDP leads to an increase on the real public expenditures at a rate of $1 \%$. And the parameter predicted for Model 2 is also greater than $1\left(\beta_{1}>1\right)$ as 1.27 , which is consistent with the prior expectations. However, the parameter predicted for Model 3 takes a value of 0.92 , which is close to but below the prior expectations $\left(\beta_{1}>1\right)$. For Models 4 and 5; the predicted co-integration coefficients are revealed to be greater than one, $\left(\beta_{1}>0\right)$ being 0.28 and 0.26 respectively, which are consistent with the prior expectations. The results of the analyses obtained within this context suggest that, within the scope of the different models that explain the relationship between the public expenditures and economic growth, a long term relationship with positive direction is present between the two variables. Therefore, in the said economies, the validity of Wagner's Law, which is based on the elasticity indicated above, shall not be rejected.

The Panel DOLS estimation method is utilized only to estimate the long term parameters. In reality, apart from the long term parameters, the short term parameters also provide essential information. In this regard, both the long and short term parameters between the aforementioned variables are analyzed by the PMGE and MGE estimation methods. The 
prediction results of the PMGE and MGE which were conducted in this regard are presented in Table 7.

Table 7. Panel long and short run estimation

\begin{tabular}{llcc}
\hline & & PMGE & MGE \\
\hline \multirow{3}{*}{ Model 1 } & EC & $-0.2909951^{*}$ & $-0.4047928^{*}$ \\
& Short Run & -0.0277879 & -0.0876921 \\
& Long Run & $1.047077^{*}$ & $0.9978453^{*}$ \\
\hline \multirow{3}{*}{ Model 2 } & EC & $-0.2865297^{*}$ & $-0.4292954^{*}$ \\
& Short Run & -0.0175027 & -0.0876119 \\
& Long Run & $1.034399^{*}$ & $0.8635952^{*}$ \\
\hline \multirow{3}{*}{ Model 3 } & EC & $-0.2381859^{*}$ & $-0.3739916^{*}$ \\
& Short Run & 0.0133814 & -0.0769823 \\
& Long Run & $1.246192^{*}$ & $1.15317^{*}$ \\
\hline \multirow{3}{*}{ Model 4 } & EC & $-0.2904721^{*}$ & $-0.403961^{*}$ \\
& Short Run & $-0.7359931^{*}$ & $-0.6812932^{*}$ \\
& Long Run & $0.0472001^{*}$ & -0.0039261 \\
\hline \multirow{3}{*}{ Model 5 } & EC & $-0.2862593^{*}$ & $-0.3913725^{*}$ \\
& Short Run & $-0.7265561^{*}$ & $-0.6690758^{*}$ \\
& Long Run & $0.0344169^{* * *}$ & 0.0224613 \\
\hline
\end{tabular}

$* 1 \%, * * 5 \%$ and $* * * 10 \%$ significant at the test values.

In Table 7, the prediction of the panel error correction with the PMGE and MGE predictors is displayed. According to the short term analyses, the error correction parameters are negative and significant for all the parameters. This parameter indicates the speed of the short term variations series, resulting from being not stable to reaching to equilibrium in the next term.

According to the results of the PMGE predictions performed within the scope of 5 different models - all of which set up the validity of Wagner's Law; 29\% of the disparities (Model 1: 29\%; Model 2: 28\%; Model 3: 24\%; Model 4: 29\% and Model 5: 28\%) that occur in one term recover in the next term and get closer to their long term equilibrium. In addition, the long term parameters of the growth variables found in the models are significant and consistent to the expectations hence positive. However, the short term parameters are statistically insignificant, except for Models 4 and 5.

When all the aforementioned models are taken into consideration, according to the results of the long and short terms analyses conducted by the MGE predictor, the error correction parameter is revealed as negative and significant. This means that, $40 \%$ of the disparities that occur in any given term (Model 1: 40\%; Model 2: 42\%; Model 3: 37\%; Model 4: 40\% and Model 5: 39\%) recover in the next term and get closer to their long term equilibrium. Furthermore, the long term parameters of the economic growth variables found in the models are significant and consistent to the expectations hence positive. Apart from this, the short term parameters are statistically significant, except for Models 4 and 5. 


\section{Conclusion and Assessment}

Public expenditures have become the top agenda for the society and state, along with the emergence of states. Also, in parallel to the establishment and progress of the modern states, they have soared within the budgets of the states rapidly and inescapably. Therefore, the studies conducted on the economic effects of public expenditures have kept intensifying. However, a complete consensus regarding the direction and scale of those effects is yet to be reached.

In this study, the validity of Wagner's Law, which explains the relationship between public expenditures and economic growth, was analyzed over its alternative models by using the data from 27 OECD economies between the years 1995-2012. It has been done within the context of utilizing unit root, co-integration and error correction tests, panel data analyses, the long term co-efficiencies between public expenditures and economic growth. In order to test the relationship of co-integration, the Pedroni, Johansen-Fisher and Westerlund co-integration tests were utilized; whereas for the predictions of the long term coefficiencies, the DOLS predictor was utilized. In addition, the Pooled Mean Group Estimation (PMGE) and Mean Group Estimation (MGE) error correction models were benefited from for predicting the short term parameters between the variables. According to the empiric results; the presence of a both short and long term relationship between the public expenditures and economic growth was concluded for the period under examination. The public expenditures are influenced by the changes in the national income, as valid for all the models used in this study. Within the scope of the alternative models, the sensitivity of the public expenditures appears to be different. However, although the elasticity coefficients are different, the presence of a positive directional interaction that flows from the national income to the public expenditures is apparent. The long term coefficients that were extracted as a result of the implementation indicated that, the income elasticity of the public expenditures in the OECD countries takes a value at around 0,26-1,26. And according to the results of the short term analyses, $24-29 \%$ of the disparities occurring in one term recover in the next term (according to PMGE Predictor), or $37-43 \%$ of the disparities recover in the next term (according to MGE Predictor), and the status gets close to its long term equilibrium. In addition, it was revealed that, the long term parameters of the changes in the economic models presented in this study were significant, and according to the prior expectations, they were positive.

The results obtained from this study point out that, the growth performance in the analyzed countries causes stimulating effects on governmental expenditures hence indicating the validity of Wagner's Law. From this point of view, if the increasing trend of the governmental expenditures between 1995-2012 is considered; provided that there is no dramatic change in the economic policies, it is safe to say that, this increase shall rise even further, along with the increase in the GDP. Also, based on the findings; it can be concluded that, public expenditures, which are considered as policy tools that hold the capacity to influence the economy both in the aspects of supply and demand, have different effects in different economies, as well as different proportions that vary depending on the economical conjuncture. 


\section{References}

Afxentiou, P.C., \& Serletis, A. (1996). Government expenditures in the European Union: Do they converge or follow Wagner's Law?. International Economic Journal, 10(3), 33-47. http://dx.doi.org/10.1080/10168739600000003

Ahsan, S.M., Kwan, A.C.C., \& Sahni, B.S. (1996). Cointegration and Wagner's hypothesis: Time series evidence for Canada. Applied Economics, 28(8), 1055-1058. http://dx.doi.org/10.1080/000368496328182

Ansari, M.I., Gordon, D.V., \& Akuamoah, C. (1997). Keynes versus Wagner: Public expenditure and national income for three African countries. Applied Economics, 29(4), 543-550. http://dx.doi.org/10.1080/000368497327038

Başar, S., Aksu, H., Temurlenk, M.S., \& Polat, Ö. (2009). Government spending and economic growth relationship in Turkey: A bound testing approach. Ataturk University Journal of Graduate School of Social Sciences, 13(1), 301-314.

Bird, R.M. (1971). Wagner's 'Law' of expanding state activity. Public Finance, 26(1), 1-26.

Burney, N.A. (2002). Wagner's hypothesis: Evidence from Kuwait using cointegration tests. Applied Economics, 34(1), 49-57. http://dx.doi.org/10.1080/00036840010027540

Chang, T. (2002). An econometric test of Wagner's Law for six countries based on cointegration and error-correction modelling techniques. Applied Economics, 34(9), 1157-1169. http://dx.doi.org/10.1080/00036840110074132

Choi, I. (2001). Unit roots tests for panel data. Journal of International Money and Finance, 20(2), 229-272. http://dx.doi.org/10.1016/S0261-5606(00)00048-6

Chow, Y., Cotsomitis, J.A., \& Kwan, A.C.C. (2002). Multivariate cointegration and causality tests of Wagner's hypothesis: Evidence from the UK. Applied Economics, 34(13), 1671-1677. http://dx.doi.org/10.1080/00036840110115659

Courakis, A.S., Moura-Roque, F., \& Tridimas, G. (1993). Public expenditure growth in Greece and Portugal: Wagner's Law and Beyond. Applied Economics, 25(1), 125-134. http://dx.doi.org/10.1080/00036849300000121

Goffman, I. (1968). On the empirical testing of Wagner's Law: A technical note. Public Finance, 23, 359-364.

Gupta, S.P. (1967). Public expenditure and economic growth: A time series analysis. Public Finance, 22, 423-461.

Im, K.S., Pesaran, M.H., \& Shin, Y. (2003). Testing for unit roots in heterogeneous panels. Journal of Econometrics, $115(1), \quad 53-74$. http://dx.doi.org/10.1016/S0304-4076(03)00092-7

Kao, C., \& Chiang, M.H. (2001). On the estimation and inference of a cointegrated regression in panel data. In: Baltagi BH, Fomby TB, Hill RC (ed) Advances in 
econometrics, nonstationary panels, panel cointegration and dynamic panels, 15, 179-222. http://dx.doi.org/10.1016/S0731-9053(00)15007-8

Kolluri, B.R., Panik, M.J., \& Wahab, M.S. (2000). Government expenditure and economic growth: Evidence from G7 countries. Applied Economics, 32(8), 1059-1068. http://dx.doi.org/10.1080/000368400322110

Koop, G., \& Poirier D.J. (1995). An empirical investigation of Wagner's hypothesis by using a model occurrence framework. Journal of the Royal Statistical Society. Series A (Statistics in Society), 158(1), 123-141.

Kumar, S., Webber, D., \& Fargher, S. (2012). Wagner's Law revisited: Cointegration and causality tests for New Zealand. Applied Economics, 44(5), 607-616. http://dx.doi.org/10.1080/00036846.2010.511994

Lamartina, S., \& Zaghin, A. (2011). Increasing public expenditure: Wagner's Law in OECD countries. German Economic Review, 12(2), 149-164. http://dx.doi.org/10.1111/j.1468-0475.2010.00517.x

Levin, A., Lin, C., \& Chu, C.J. (2002). Unit roots tests in panel data: Asymptotic and finite-sample properties. Journal of Econometrics, 108(1), 1-24. http://dx.doi.org/10.1016/S0304-4076(01)00098-7

Maddala, G., \& Wu, S. (1999). A comparative study of unit root tests with panel data and a new simple test. Oxford Bulletin of Economics and Statistics, 61(1), 631-652. http://dx.doi.org/10.1111/1468-0084.0610s1631

Mann, A.J. (1980). Wagner's Law: An econometric test for Mexico, 1925-1976. National Tax Journal, 33, 189-201.

Oxley, L. (1994). Cointegration, causality and Wagner's Law: A test for Britain 1870-1913. Scottish Journal of Political Economy, 41(3), 286-298. http://dx.doi.org/10.1111/j.1467-9485.1994.tb01127.x

Payne, J.E., \& Ewing, B.T. (1996). International evidence on Wagner's Hypothesis: A cointegration analysis. Public Finance, 51(2), 258-274.

Peacock, A.T., \& Wiseman, J. (1961). The growth of public expenditure in the United Kingdom. Princeton University Press, Princeton, USA.

Pedroni, P. (1999). Critical values for cointegrating tests in heterogeneous panels with multiple regressors. Oxford Bulletin of Economics and Statistics, 61(1), 653-670. http://dx.doi.org/10.1111/1468-0084.0610s1653

Pedroni, P. (2004). Panel cointegration, asymptotic and finite sample properties of pooled time series tests with an application to the purchasing power parity hypothesis. Econometric Theory, 20(3), 597-625. http://dx.doi.org/10.1017/S0266466604203073

Pesaran, M.H., \& Smith, R.P. (1995). The natural rate hypothesis and its testable implications. In: Cross R (ed), The natural rate of unemployment: Reflections on 25 
years of the hypothesis, Cambridge University Press, Cambridge, pp. 203-230.

Pesaran, M.H., Shin, Y., \& Smith R.P. (1999). Pooled mean group estimation of dynamic heterogeneous panels. Journal of the American Statistical Association, 94(446), 621-634. http://dx.doi.org/10.1080/01621459.1999.10474156

Selen, U., \& Eryiğit, K. (2009). Is Wagner's Law valid for Turkey in the presence of structural breaks? Maliye Dergisi, 156, 177-198.

Sideris, D. (2007). Wagner's Law in 19th Century Greece: A cointegration and causality analysis. (Bank of Greece, No. 64). Retrieved June 1, 2012 from http://www.bankofgreece.gr/BogEkdoseis/Paper200764.pdf

Singh, B., \& Sahni, B.S. (1984). Causality between public expenditure and national income. The Review of Economics and Statistics, 66(4), 630-644.

Stock, J.H., \& Watson, M.W. (1993). A simple estimator of cointegrating vectors in higher order integrated systems. Econometrica, 61(4), 783-820.

Wagner, A. (1883) Three extracts on public finance. In: Musgrave R.A., \& Peacock A.T. (ed) (1958) Classics in the theory of public finance, Macmillan, London.

Westerlund, J. (2006). Testing for panel cointegration with multiple structural breaks. Oxford $\begin{array}{llll}\text { Bulletin of Economics and Statistics, 68(1), 101-132. } & \text {. }\end{array}$ http://dx.doi.org/10.1111/j.1468-0084.2006.00154.x

Westerlund, J. (2007). Testing for error correction in panel data. Oxford Bulletin of $\begin{array}{llll}\text { Economics } \quad \text { and } & \text { Statistics, }\end{array}$ http://dx.doi.org/10.1111/j.1468-0084.2007.00477.x

\section{Copyright Disclaimer}

Copyright for this article is retained by the author(s), with first publication rights granted to the journal.

This is an open-access article distributed under the terms and conditions of the Creative Commons Attribution license (http://creativecommons.org/licenses/by/3.0/). 